\title{
Individual Belief and Practice in Neopagan Spirituality
}

\section{Basic components of postmodern spirituality}

Postmodern spirituality is basically characterized by a set of elements which constitute the framework of spiritual belief and practice: the underlying importance of subjective experience, the interpretation of this personal experience according to, for example, Eastern, occult or mystical traditions, a definite distancing from the dogma of religious organisations with a tendency towards anti-institutionalism and stressing the religious autonomy of the practitioner. This leads to an integrated interpretation of the world for the individual and to the notion of 'spirituality' becoming an alternative for the notion of 'religion' for the practitioner (Knoblauch 2006: 106-8). Based on these observations it can be postulated that all spirituality is temporary, as practitioners do not focus on a fixed aim in life, but rather on the ways and means to find and approach an aim like this (Ebertz 2005: 207). These components function as a map for spiritual individualism and for neopagan spirituality as well.

\section{Two basic common characteristics of neopagan spirituality}

Neopaganism is one of the fast growing spiritual practices today. Estimations of numbers vary. Helen Berger estimates that there are about 200,000 neopagans in the United States and takes the figure of 300,000 posited by Aidan Kelly as the basis for her more conservative number (Berger 1999: 9). The National Census carried out by the Office of National Statistics in the United Kingdom in 2001 found a total of 38 ,000 pagans including the most prominent group of Wiccans, with 7,000 members-which in comparison with, for example, Baha'i $(5,000)$ is a significant number (Office for National Statistics 2004).

Neopagans are often placed in the field of new religions and new religious movements. When focussing on the world-view shared by these groups, this classification is correct. But when dealing with the individual shaping of neo- 
pagan belief and practice, neopaganism unfolds as a complex field of personally coined spirituality, where the elements of belief and religious practice are based on individual experience: 'Witchcraft, and paganism generally, is a religion where experience is primary-the written word, whilst useful, is very much secondary' (Heselton 2003: 273). Experience must basically be seen as the permanent activity of processing impressions on the senses and dealing with always differing situational contexts, reverting to established and modifiable structures, anticipating future situations as well as the element of imagination as a way to build up a relation to the world (Laing 1971: 25). The result is that no neopagan practitioner believes and practices like another. Berger states that 'it is possible for each individual to have her or his own brand of Neo-Paganism' (Berger 2003: 3), and Margot Adler cites a neopagan who had written to her: 'I don't think Pagans share any beliefs! And no Witches think alike!' - as well as the journalist Susan Roberts who said: 'Witches defy categorization' (Adler 1997: 354).

Neopaganism has no dogma, but before focussing on the individuality of neopagan spirituality it is important to explain the two basic assumptions which constitute the world-view shared by most neopagans. The first element of neopagan belief is the assumption of the sacredness of nature and of the world. Whereas other religions differentiate between a mundane/material realm and a sacred/divine realm, neopagans believe in the structural correspondence of the sacred and the profane. To them the profane does not exist in so far as it is always identical with the sacred. Neopagans believe in the structural unity of the material world and the sacred space of the divine: to them the natural world human beings live in is sacred. The whole world is seen as a sacred system which includes nature, animals, humans and, depending on the personal spiritual concept, divine entities such as gods. For neopagans humans are not separate from divinity, but are structurally related to it. As it is semantically not satisfying to explain this concept in terms of negation (not separate), this structural relation is referred to by the positive notion of congruence (Rensing 2007: 130-4). According to Linda Woodhead and Paul Heelas's distinction between 'religions of difference, 'religions of humanity' and 'spiritualities of life', neopagan spirituality belongs to the last category as it locates 'the sacred within the self and nature, rejecting the idea that the spiritual is essentially different from what lies within the very order of things' (Woodhead \& Heelas 2000: 15). By focussing on the sacredness of nature and man the neopagan world-view is based on the structural identity of the sacred and the profane. In a clearly defined contrast to the 'religions of difference', neopaganism can be called a spirituality of congruence. 
The second belief shared by neopagans concerns the divine being seen as both female and male. For them human experience in nature and world operates as evidence for this belief. Based on the concept of congruence many neopagans worship both goddesses and gods. This element is also very important to them, because it once more opposes their belief to the monotheistic dogma of Judaism, Christianity, and Islam, where the one exclusive god is described in terms of male characteristics (feminist theology being a section of theology as a complex field of study still may be called marginal; representatives are, for example, Elga Sorge, Christa Mulack and Mary Daly).

\section{Composing poetry—expressing spirituality}

Apart from these two elements, neopagan spirituality is flexible and personal. This individual spirituality is expressed in the art of poetry. Since the early years of neopaganism, that is the 1940 s and 1950 s, poetry has played an important role. Especially Doreen Valiente, who is called the mother of modern witchcraft, produced poetry to express the basic elements and to create ritual lyrical texts of witchcraft. Today neopagans take this as a model for expressing their feelings, beliefs and experience through composing their own personal spiritual poetry. Lyrical art is a vital practice, as it is a way to deal with one's own spirituality, to clarify emotions and to point out troubling feelings. It basically helps neopagans to define their own place within the world:

Who needs poetry? Pagans do... For today's Wiccans and Pagans, poetry is essential. We have many books of ritual, but no standard liturgy. Instead, we have the freedom-and the responsibility - to craft our own rituals. We must choose words that connect us with the Divine, nurture our spirits, and challenge us to become more aware. Good poems do all this and more. (Raeburn 2003: ix.)

To neopagans composing poetry is a way of communicating with the divine and is a spiritual experience:

Unlike members of more conventional faiths, Pagans need not-often cannot-follow the book, sticking comfortably to another's words. We must choose the words we use to express our spiritual truths, must consider and study those truths, then search for ways to bring them to life. It is work, no 
more and no less, though it is often work that feeds our souls, hearts, and minds. (Raeburn 2003: ix.)

Poetry in neopaganism may be composed for oneself alone, for others, to be used in a ritual context or just to be read in some place of calm during a moment of worship. It is a vital practice to 'connect to the Pagan spirit' and it is characterized by strong emotionality (Raeburn 2003: $\mathrm{x}$ ). In this context poems are texts for use, spiritual texts and texts of communication. Arianna Moonlightshadow explains: 'My personal Wiccan poetry does sometimes serve as communication with the Lord and Lady... Rhyming has an ability to make it meaningful. . . it requires you to draw on your inner creative spirit and helps to make a greater connection.' (E-mail to the author on 6 July 2004.) And Zelda of Arel describes her state of mind while composing poetry: 'I feel calm and serene. Sometimes like in a circle.' (E-mail to the author on 5 August 2004.) Of course, the notion of lyrical ritual language does not imply that verses have to rhyme. Rather this kind of language differs from everyday language by the lyrical use of metre, choice of words, metaphors, the way of argumentation, strong subjectivity, which in this case I like to call religious/spiritual subjectivity, and the way of presentation, as for example, lyric iconicity (Müller 1995: 95). When shared between neopagans, which is very often the case, they function as vehicles of spiritual belief as they give rise to communication and interchange between neopagans. On the one hand they display the highly individual personal feelings of the composer/poet, on the other hand they may serve as texts of recognition and identification. Gavin Bone explains: 'when one person starts to express that and put that down other people will. . . read it and go "Yes, that's what I feel"' (Farrar \& Bone 2004). This poetry in neopaganism on the one hand mirrors the search for one's own spiritual view in the present, and on the other hand gives impulses for the development of neopaganism in the future.

\section{The characteristics and functions of neopagan poetry}

One important function of neopagan lyrical texts is the communication with the divine, that is, connecting to goddesses and gods and stabilizing this connection. Many poems dealing with the various functions and aspects of gods are introduced and structured by the rhetoric figure of apostrophe. By this the reader learns about the countless possibilities of combinations of goddess and god concepts. The following examples show this variety: 
The goddess may be seen as Mother Earth, which may be combined with addressing the god, as in 'Dear Mother of the Earth and Seas,/ Dear father at her side' (A Devotional, 5f). Many poems include several verses that display an address to the divine: 'Divine Mother, Goddess of Light', 'Holy Mother, Queen of Heaven and Earth' and 'Heavenly Goddess' (The Goddess is alive, $21,25,27)$. Apart from this one finds invocations of various goddesses known from different pantheons: 'Demeter', 'Demeter, Mother' (Honor to the Goddess, Lady of Many Names, 13, 24), 'Hecate' (Hecate Chant Invocation, 5) and 'Homage to thee, Oh Sun Goddess./ O you glorious being' for the Sun Goddess Amaterasu, known as a central kami in Shinto (Amaterasu II, 1f). Readers get to know the 'Shimmering-throned immortal Aphrodite,/ Daughter of the Creatrix, Enchantress' (Aphrodite II, 1f) and the 'Honored Crone of change/ Ancient One of Transition' (Honor to the Goddess, Lady of Many Names, 12f). In Four Invocations iv, even a whole set of goddesses is addressed: 'Venus, Hecate, Persephone, Aphrodite' (4). One finds the 'Lyregifted Apollo, 'O farsighted father of prophecy' (Song of Praise to Apollo, 1, 9), 'Dionysus' the 'old voyeur' and 'Old deviant father, incestuous friend and jealous rival' (Dionysus in the Curtains, 1f, 19) as well as 'O Mighty Pan' (We, The Enchanted, 1).

In neopaganism goddesses and gods may be combined according to their classical function, the sound of their names and the partners with whom they share the pantheon. This combination especially depends on the situational needs of the individual practitioner. The possibilities of combination are innumerable. Each practitioner chooses her or his communicative divine opposite partner. The addressing phrase states which function of divinity is important for the practitioner at the very moment. The eclectic character of this individual neopagan practice becomes just as evident as the high emotionality mirrored by the emotive mode of expression realised by the 'O'.

Neopagans compose lyrical texts on various topics. Each text is created on a highly individual basis and deals with themes that are important to the author/poet. As we have already seen, poems may be composed as invocations to the gods or texts for occasions of prayer and worship. A significant number of poems deal with death and the lyrical I's way of coping with it. The poem The Maiden, The Mother, The Crone iconically evokes the picture of a flickering candle next to the scene of relatives sitting at an old woman's death bed, while the dying woman remembers how her goddess was always there to guide her through life. The poem The Hanged Man and The Ten of Swords relates the fact of inevitable death to the meanings of the two tarot cards which explain the message, that man has to let go of life-her or his own life and that 
of others-one day. The poem tells the addressee that as the brown leaf at the end of autumn has to let go of the branch and fall to the ground, it is unavoidable for all creatures to face death eventually. This poem also points at the new beginning, the next spring following the coming winter, a topic which is the central theme in many other texts: the wheel of the year and the eight neopagan seasonal festivals. The year's turn including the basic elements of coming and going, growing, harvesting, being born and dying mirrors the cyclical time model of neopagan spirituality. Of the eight seasonal festivals Samhain, celebrated on the 31 October, seems to be the most popular date, because it is the main topic of many neopagan poems. Another important topic is the neopagan self-consciousness, which is dealt with in poems that comment on the strange appearance of neopagan spirituality to outsiders and on the feeling of being a neopagan. Some poems go deep into the mysteries of neopagan belief and spirituality and by this touch the obviously most important topic of all: nature.

\section{Nature in neopagan poetry}

Neopagan belief is based on the assumption that everything on earth, including minerals, plants and creatures, is alive and that everything has its own spiritual power. The earth, the world, the whole universe is seen as a huge sacred living organism (Crowley 2001: 21). Therefore woods, lakes, mountains, all vegetation and nature are very important to neopagans. To them they are the source of the secrets of life and reveal the answers to all significant questions. This is explained in the poem The Mysteries by Doreen Valiente:

Here and now are the Mysteries.

Out of no stored and storied past

Of things long lost;

But the breathing moment of time.

Out of no twilight

But that which falls upon the hills this night.

The old trees partake of them,

And the voices of the grass;

The ghost-white blossomed elders,

And the first clouded glow

Of the rising moon.

If we can hear, 
If we can see,

Out of no buried past they come;

But from the fields of our own home

Is reaped the grain

That makes the bread of their feast.

Out of the flowers of every summer

Flows the honey of their mead.

Look, between the stones is a blade of grass;

And all the rites of the high Mysteries,

And the runes of all witcheries,

Are written upon it.

The poem is structured by numerous anaphors and parallelisms ('Out of no stored and storied past' (2), 'Out of no twilight' (5), 'Out of no buried past' (14), 'But... $(4,6,15))$. It tells the addressee that the mysteries of life and of man's existence cannot be discovered from past centuries and from antiquated ideas, which is phonologically expressed by the combination of alliteration and assonance in 'stored and storied' and 'long lost'. All answers are presented in the present, that is 'Here and now' and virtually 'breathing', which means in this very second, stressed by the focus on the [i:] sound. The text argues that the basis of all life is nature. By pointing at the regular and basic principles of man's relation to nature, the natural rhythm of day and night, harvesting, and blossoming, the poem invites the addressee to search for answers in his daily life. But it is important to 'hear' and 'see', and finally to 'look' closely, because each 'blade of grass' carries the relevant information, which has to be read by man. To neopagans nature not only gives, but itself is the answer to life.

Because of nature being the centre for neopagan spirituality, pictures and metaphors presenting elements from the natural world are almost omnipresent in neopagan poems, but their function and their metaphorical design always depends on the individual poet's preferences, moods and ideas. One element is the moon, which is connected to the goddess principle in neopaganism. The moon may be presented as a 'silver disk of light' (Moon Song 4), a 'torch' (Hecate Chant Invocation 9), which is an interesting picture, because it transforms the light-reflecting moon into a light-radiating moon, and as a 'half-eaten. . yellow apple' (Vigil 1f). This metaphor-simile combination is interesting, because it explicitly presents an element of nature, the moon, by another element of nature, the apple. Another important element found in neopagan poems is the light/darkness and day/night contrast, which is also evident in the above-mentioned metaphors presenting the moon. In the short 
and trenchant poem In Broad Daylight the author Candace Walworth plays with this contrast by creating a visually established paradox:

Night hides in the bark

of pines under rocks and

between toes

Like a stray cat begging

for milk or a bite of fish

night lingers

all day

This poem is a good example for focussing on the senses. Presentations of hearing, seeing, smelling, touching are important tools for neopagan poetry. In this context the poem Blackberries is an impressive attack on the sense of taste:

filled with the sweet, thick

black-red blood of the dying sun-god,

dark taste of lengthening nights

in the full heat of summer.

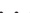

those who do not ripen fully

remain too red, too hard, too sour,

on the vine, never entering

the sharp gated, pink-tongued mouth,

to be squeezed and shredded by desire,

to enter the hot blood of the devouring creature

whose opening and closing black center

is ever-scanning for the next mouthful of perfect

purply plumpness... (1-15)

One of the most important elements of nature in neopagan poetry is the tree. Trees function as symbols for nature and life in general and are basically characterized as living entities. Trees are often presented as having feelings and communicating with their environment: they whisper, sing, are peaceful, wise and graceful, they hail to the gods and wear their leaves like a dress. By attributing human feelings and habits to trees pagan authors use the poetic figure of 
personification to place trees-and with them all other elements of natureon a level with human beings. The poem The Tree's Sight by Zelda of Arel is an example for the personification of trees:

The spirit of Air

Kisses the living

Monument from Earth.

It speaks with

The help of Wind

Telling a story.

The spirit of Water

Giving me drink

From Air and Earth.

The spirit of Fire

Destroying me

With scolding flames.

Human hands

Break my arms,

Setting on fire.

They gather my

Fallen dead arms

Setting on fire.

I gaze on those

Not hurting me

Wondering a bit.

Stars shine around

Their moving,

Bowing necks.

They must be

Riting Pagans

From the city. 
The interesting point of this poem is not only the expression of the tree's thoughts and feelings and the pain it has to suffer from man's attack, but also the idea that the tree is able to tell from their behaviour what kind of people they are, here namely pagans. By means of anthropomorphization the tree is presented as having self-awareness and consciousness and is presented as a thinking being able to differentiate between people. Here the tree functions as a representative for nature as a living organism and urges man not only to accept the common roots but also to act according to this insight.

\section{Neopagan ritual composition}

The poem leads to another important element of neopagan spirituality: the element of ritual. Rituals can be held virtually everywhere, at any place that seems appropriate. According to the principle of congruence no place is better or more fitting than another, because every place is a sacred place. The individual chooses where to establish the sacred space for the ritual, which means that the place is defined as a ritual working space by establishing a ritual circle. Places may be chosen according to the individual's preference for indoor or outdoor locations, according to the current occasion or time of day. Many practitioners have their favourite places. The practitioner uses certain implements, may integrate personal objects and usually wears special clothes. Each ritual is planned and structured individually depending on the occasion and the purpose. Texts are written to be read or quoted from memory during the ritual, for making a request to the gods or for thanking them. For example, the pagan poet Zelda of Arel regularly recites the first lines of her poem Wiccan Night for casting the ritual circle: 'Warm lights awake/ In the cold depths of night./ One by one they/ Become a circle of rite. . ' (E-mail to the author on 5 August 2004). It has already been explained that the goddesses and gods and combinations of them as well as their degree of importance are individual for each practitioner. Considering the fact that more than 50 per cent of all neopagans are solitary practitioners creating rituals on their own it is easy to imagine the variety of possibilities (Berger 1999: 50).

The reason for a neopagan to practice alone may, for example, be the long distance to other pagans or ignorance about other neopagans in the surrounding area. But an important reason for being a solitary pagan is a tendency toward strong individuality. This individuality is not only characterized by the personal concept of divinity and the individual elements of belief, but also by the fact that these individual concepts may well change on the basis of 
the practitioners' experience and the interest in trying and discovering new pagan traditions. Therefore it is not appropriate to speak of fixed concepts of belief, but rather of a permanent flow of modification of neopagan ideas.

However even solitary pagans usually meet on special occasions in order to get in contact with others to talk and exchange thoughts and ideas. Meetings may be arranged on the seasonal festivals or held once a year. For festivals and conferences at least one ritual is usually planned and prepared by the organization committee. Meetings and festivals that last several days often offer workshops on ritual planning and practice (Magliocco 2004: 122-30; Pike 2001: chapter 2). The first German conference of thPagan Federation International took place in Witten, Northrhine-Westfalia, in 2004, and was attended by about 100 pagans who participated in several workshops such as 'Progressive Witchcraft', 'Ägyptische Ritualmagie,' 'Santeria' and 'Modern Irish Druidcraft', just to mention some of the topics, to illustrate the variety of possible neopagan interests (Programme 2004). During the conference all visitors attended a group ritual that had been prepared by the board members. In the concert hall of Haus Witten in the middle of the room an altar had been put up, carrying various Wiccan and neopagan tools, for example, an athame (ritual knife) made of dark wood. All the participants formed a huge circle around the altar. A priestess and a priest led the ritual, which started by casting the ritual circle by the priest using the athame. The corners and elements of earth, air, fire and water were invoked by reciting verses written by Rilke, Goethe and Droste-Hülshoff. During the ritual chalices filled with fruit juice were passed clockwise while each person said a couple of friendly words to her or his neighbour. Eventually participants began to sing with increasing volume: 'Wir sind ein Kreis in einem Kreis, ohne Anfang und ohne Ende' (We are a circle within a circle, with no beginning and no end). To prepare a ritual like this one, participants have to negotiate not only their preferences but also have to consider what might be agreeable for the other unknown participants. Especially the cooperation in the circle and the inclusion of each participant has to be decided on. In Witten a strong sense of community was achieved by singing together and especially by helping to establish the ritual circle by saying some words and offering good wishes to one's neighbour.

Pagans working in a group have to deal with the phenomenon of negotiating rituals regularly. The planning of a ritual usually starts with the analysis of the purpose, aim or motivation and other determining factors such as, for example, the actual numbers of participants and the weather conditions. Then follows the collection of different ideas as to how the topic can be translated into ritual action. The participants discuss several suggestions and eventually 
decide on certain elements. Ideas and suggestions that are not realized might later be incorporated into some other ritual. Other items of negotiation are the sequence of elements, the role of each participant and the preparatory work such as, for example, the use of candles, incense, semi-precious stones and other tools, which correspond with the theme of the ritual and which have to be purchased in advance. Participants have to decide on a date that matches the subject matter - for example, the phase of the moon or the planetary hour. Planning and negotiation in this or a similar way is the custom in neopagan group activities today.

\section{The importance of art in postmodern spirituality}

The process of composing and performing a ritual, whether solitarily or in a group, is seen by neopagans as creating a piece of art. The practitioner/artist incorporates her or his personal feelings, thoughts and hopes during the phase of planning and especially when performing a ritual. The 'creative process of ritual invention' and the performance 'move participants towards transcendence and greater understanding chiefly through ... aesthetic charge; this is what allows good rituals to become ... vehicles for changing our consciousness' (Magliocco 1996: 97, 99). The same, as this article has shown, is true for neopagan poetry. Practitioners of this way of spirituality, where there are no texts or other sources telling them what to believe and how, turn to producing art for their personal spiritual development. While dogma is strictly rejected in postmodern spirituality, art obviously has become a very important element on the individual's way to find her or his place in life and in the world.

\section{References}

\section{Literature}

\section{Adler, Margot}

1997 Drawing Down the Moon: Witches, Druids, Goddess-Worshippers, and Other Pagans in America Today. New York: Penguin Compass.

\section{Berger, Helen A.}

1999 A Community of Witches: Contemporary Neo-Paganism and Witchcraft in the United States. Columbia: University of South Carolina Press.

2003 Voices from the Pagan Census: A National Survey of Witches and Neo-Pagans in the United States. Columbia: University of South Carolina Press.

\section{Crowley, Vivian}

2001 Way of Wicca. London: Thorsons. 


\section{Ebertz, Michael N.}

2005 Spiritualität im Christentum und darüber hinaus: Soziologische Vermutungen zur Hochkonjunktur eines Begriffs. Zeitschrift für Religionswissenschaft 13 (2): 193-208.

\section{Heselton, Philip}

2003 Gerald Gardner and the Cauldron of Inspiration: An Investigation into the Sources of Gardnerian Witchcraft. Milverton: Capall Bann Publishing.

\section{Knoblauch, Hubert}

2006 Soziologie der Spiritualität. In: Karl Baier (ed.), Handbuch Spiritualität: Zugänge, Traditionen, interreligiöse Prozesse; pp. 91-111. Darmstadt: Wissenschaftliche Buchgesellschaft.

\section{Laing, Ronald D.}

1971 Phänomenologie der Erfahrung. Frankfurt am Main: Suhrkamp.

\section{Magliocco, Sabina}

1996 Ritual is My Chosen Art Form: The Creation of Ritual as Folk Art among Contemporary Pagans. In: James R. Lewis (ed.), Magical Religion and Modern Witchcraft; pp. 93-119. Albany: State University of New York Press.

2004 Witching Culture: Folklore and Neo-Paganism in America. Philadelphia: University of Pennsylvania Press.

\section{Müller, Wolfgang G.}

1995 Das Problem der Subjektivität der Lyrik und die Dichtung der Dinge und Orte. In: Ansgar Nünning (ed.), Literaturwissenschaftliche Theorien, Modelle und Methoden: Eine Einführung; pp. 93-105. Trier: WVT. (WVTHandbücher zum literaturwissenschaftlichen Studium, 1)

Pike, Sarah M.

2001 Earthly Bodies, Magical Selves: Contemporary Pagans and the Search for Community. Berkeley: University of California Press.

Raeburn, Jane (ed.)

2003 The Pagan's Muse: Words of Ritual, Invocation, and Inspiration. New York: Citadel Press.

\section{Rensing, Britta}

2007 Die Wicca-Religion: Theologie, Rituale, Ethik. Marburg: Tectum Verlag.

Woodhead, Linda \& Paul Heelas (eds)

2000 Religion in Modern Times: An Interpretive Anthology. Oxford: Blackwell Publishers.

Other sources

\section{Farrar, Janet \& Gavin Bone}

2004 Interview by Britta Rensing on the First Conference of the Pagan Federation International Deutschland, 9 October 2004.

\section{Office of National Statistics}

2004 National Survey for 2001. Published on 11 October 2004. http://www.statistics.gov.uk/CCI/nugget.asp $? \mathrm{ID}=954 \& \mathrm{Pos}=\& \mathrm{ColRank}=2 \& \mathrm{Rank}=192 \quad(\mathrm{ac}-$ cessed on 3 January 2005). 


\section{Programme}

2004 Programme of the 1st Conference of the Neopagan Federation International

Deutschland, Witten, Northrhine-Westfalia, 9 October 2004.

\section{Poems}

Amaterasu II by Anna Livia Plurabelle. http://www.sacred-texts.com/wmn/bog/ bog11.htm (accessed on 19 July 2003).

Aphrodite II by Anna Livia Plurabelle. http://www.sacred-texts.com/wmn/bog/ bog $18 . h$ tm (accessed on 19 July 2003).

Blackberries by Susan Kennedy. In: Raeburn 2003: 58 .

A Devotional by Arawen. http://www.geocities.com/Athens/Delphi/3781/ (accessed on 10 August 2003).

Dionysus in the Curtains by Frank Miller. In: Raeburn 2003: 141-2.

Four Invocations: iv by Tish Eastman. In: Raeburn 2003: 84.

The Goddess is alive by unknown author. http://www.sacred-texts.com/bos/bos376. htm (accessed on 18 July 2003).

The Hanged Man and The Ten of Swords by Mary Ann Murphy. http://www.feri.com/ frand/shaman4.html\#thehangedmanand (accessed on 10 August 2003).

Hecate Chant Invocation by Lady Gueneva. http://www.witchvox.com/poetry/dt_ po2.html?a=uspa\&id=702 (accessed on 14 February 2006).

Honor to the Goddess, Lady of Many Names by Karen Ethelsdattar. In: Raeburn 2003: 15-17.

In Broad Daylight by Candace Walworth. In: Raeburn 2003: 52.

Moon Song by Ravenwitch. http://www.members.lycos.co.uk/ravenwitch/487/linkso. html (accessed on 10 August 2003).

The Maiden, The Mother, The Crone by unknown author. http://www.wiccanway.imess.net/poetry.html> (accessed on 10 August 2003).

The Mysteries by Doreen Valiente. In: Doreen Valiente, Natural Magic; p. 12. Blaine: Phoenix Publishing, 1975.

Praisesong to Apollo by Elizabeth Barrette. In: Raeburn 2003: 33 .

The tree's sight by Zelda of Arel. http://www.wiccanlane.itgo.com/poetry/wiccan. htm (accessed on 10 August 2003).

Vigil by Sarah Brown Weitzman. In: Raeburn 2003: 118-19.

We, The Enchanted by Doreen Valiente. In: Doreen Valiente, Charge of the Goddess; p. 44. Brighton: Hexagon Hoopix, 2000.

Wiccan Night by Zelda of Arel. http://www.wiccanlane.itgo.com/poetry/wiccan.htm (accessed on 10 August 2003). 